\title{
KERJA SAMA ANTARKELOMPOK DAN KETERBUKAAN BERPIKIR ILMIAH MATA KULIAH SAINS LANJUT BERPRAKTIKUM MAHASISWA PGSD
}

\section{COOPERATION BETWEEN GROUPS AND OPENNES SCIENTIFIC THINKING IN SAINS SUBJECT AT PRIMARY TEACHER EDUCATION STUDENTS}

\author{
Panji Hidayat \\ Program Studi PGSD, FKIP, Universitas Ahmad Dahlan Yogyakarta \\ E-mail:phidayat81@gmail.com
}

\begin{abstract}
ABSTRAK
Penelitian ini bertujuan untuk mengetahui peningkatan kerjasama antarkelompok dan membangun keterbukaan berpikir ilmiah pada mata kuliah sains lanjut saat melakukan kegiatan praktikum. Penelitian dilaksanakan di Laboratorium FMIPA kampus 3 Universitas Ahmad Dahlan. Jenis Penelitian ini adalah Penelitian Tindakan Kelas (PTK) dengan sampel penelitian mahasiswa PGSD semester 3 kelas D, E, F, dan G yang berjumlah 171 Mahasiswa. Siklus penelitian ini terdiri dari 2 siklus dan setiap siklus dilaksanakan dengan dua kali praktikum. Analisis data yang digunakan dengan menghitung rerata angket kerjasama antarkelompok dan angket keterbukaan berpikir ilmiah yang kemudian dicari selisih rata-rata dari kedua siklus. Hasil penelitian ini menunjukkan bahwa ada peningkatan kerjasama antarkelompok dan keterbukaan berpikir ilmiah. Peningkatan kerjasama antarkelompok ditunjukkan dengan kenaikan skor rata-rata 74,31 siklus I menjadi 78,46 pada siklus II. Sedangkan peningkatan keterbukaan berpikir ilmiah ditunjukkan dengan kenaikan skor rata-rata 82,98 siklus I menjadi 87,12 siklus II.
\end{abstract}

Kata Kunci: kerja sama antar kelompok, keterbukaan berpikir ilmiah

\section{ABSTRACT}

This research aims to determine the improvement of cooperation between groups and build openness scientific thinking in advanced science courses while doing lab activities. Research conducted at the Laboratory of Natural Sciences 3 Ahmad Dahlan University campus. This type of research is classroom action research (PTK) with samples of student research PGSD 3rd semester classes $D, E, F$, and $G$ are numbered 171 students. This study cycle consists of two cycles and each cycle carried out with twice the practicum. Analysis of the data used to calculate the average questionnaire intergroup cooperation and openness questionnaire scientific thinking then searched the average difference of the two cycles. Results of this study indicate that there is an increase in inter-group cooperation and openness of scientific thinking. Improved inter-group cooperation shown by the increase in the average score of 74.31 the first cycle to 78.46 in the second cycle. While the increased openness of scientific thinking indicated by the increase in the average score 87.12 82.98 first cycle to the second cycle.

Keywords: inter-group cooperation, openness of scientific thinking 
Pendahuluan

Segala perkembangan tidak hanya menggembirakan rakyat dan pemerintah, karena akan menuntun bangsa kita ke arah kemajuan. (Ki Hajar Dewantoro, 1997: 215). Perkembangan ilmu pengetahuan menimbulkan inovasi dan banyak perubahan positif dalam kehidupan. Zaman semakin cepat berubah dan iklim kompetitif juga semakin ketat. Oleh karena itu, perlulah manusia untuk belajar. Kata "Belajar" adalah kegiatan dahsyat yang menyebabkan si Pembelajar semakin merasa dirinya lapar akan pengetahuan. Belajar bukan untuk anak sekolah saja. Namun, belajar adalah long life education di belahan bumi manapun manusia berada. Menurut D.A. Benton belajar adalah kebutuhan setiap manusia. Belajar merupakan salah satu kunci meraih kesuksesan dalam segala profesi apapun dengan mengembangkan potensi diri.

Pengetahuan yang bertambah membuka kesempatan besar untuk berkembang dalam karier, prestasi, ataupun persaingan dalam segala hal. Pengetahuan dan keterampilan yang didapatkan dari kebiasaan belajar juga dapat menjadi alat ampuh untuk membantu mengambil keputusan yang berkualitas. Dengan kemampuan yang terasah akan lebih bijak melihat suatu permasalahan dari sudut pandang yang lebih luas. Hal ini akan membantu menentukan pilihan solusi yang lebih beragam dan lebih tajam.
Belajar adalah kewajiban setiap manusia. Bukan tidak mungkin, meskipun sudah mendapatkan tanda kehormatan profesor, diharapkan guru besar melahirkan karya ilmiah dengan tidak meninggalkan kegiatan belajar, baik riset maupun nonriset. Jadi, belajar sangat penting selama masih ada kesadaran bahwa kehidupan ini mengalami perubahan yang cepat dan dinamis sesuai dengan dinamika kehidupan. "Tidak ada yang abadi di dunia ini, kecuali perubahan". Belajar adalah ciri bahwa manusia hidup. Tidak belajar berarti telah memadamkan api kehidupan. Belajar membuat manusia menciptakan ilmu pengetahuan yang sifatnya terminalis, sehingga ilmu pengetahuan yang pernah diciptakan tidak akan pernah mengalami kesempurnaan. Hal ini tidak lain dan tidak bukan karena kuriositas manusia yang selalu ingin mencari kebenaran, kecuali kebenaran Sang Pencipta yang sifatnya mutlak. Untuk mendapatkan keahlian dan kompetensi khusus dari suatu profesi diperlukan suatu pendidikan dan pelatihan khusus juga. (Suwatra, 2014: 51). "Manusia pembelajar" (mengambil istilah dari Andreas Harefa) memiliki makna bahwa sejatinya manusia memiliki kewajiban mengeksplorasi apa yang dimilikinya.

Sebagai homo educandum, manusia juga memiliki tanggung jawab untuk belajar dan selalu menggali diri (Who am I). Dengan demikian, manusia mampu mengaktualisasikan diri sampai quantum keemasan to be the best. 
Co-Opetition juga sangat diperlukan untuk pencerahan di saat pikiran mengalami jalan buntu. Douglas Brown, seorang pakar bahasa mengatakan bahwa apabila si Pembelajar ingin belajar sukses membutuhkan komitmen secara fisik, mental, dan emosional. Komitmen secara fisik, misalnya meluangkan waktu dalam belajar dan mencari sumber belajar. Komitmen secara mental dapat dilakukan dengan mengaitkan informasi dengan pengalaman diri. Sementara itu, komitmen emosional dapat dilakukan dengan menyukai apa yang dipelajari. Dengan demikian, muncul rasa senang dan mampu bertahan pada situasi belajar yang sulit untuk dicerna. Salah dalam belajar lebih baik daripada salah dalam praktik yang sifatnya urgen.

Dunia yang bergerak cepat ini, banyak perubahan yang terjadi. Untuk mengendalikan perubahan tersebut, belajar merupakan dasar kehidupan dengan kecepatan yang seimbang atau melampaui kecepatan perubahan tersebut. Kompetensi pengetahuan dan keterampilan adalah kompetensi yang mudah dinilai, diberikan, dilatihkan, diajarkan, dialami, dan dikembangkan karena merupakan kompetensi yang berada di permukaan cenderung mudah dilihat (Supardi, 2013: 145). Belajar adalah keharusan bagi setiap manusia. Namun cara yang digunakan berbeda-beda. Belajar sangat berpengaruh pada kemampuan berpikir anakanak dalam mencapai kedewasaan. Belajar untuk mahasiswa berbeda dengan anak-anak karena mereka sudah mempunyai bekal pengetahuan dasar yaitu membaca, menulis, dan berhitung. Bagi yang longgar hati ada kesempatan bagi mahasiswa untuk mempelajari bahan-bahan perkuliahan yang sudah dipersiapkan dosen untuk dipelajari lebih lanjut. Contohnya saja adalah kegiatan berpraktikum yang sudah ada modul.

\section{Mahasiswa} tinggal untuk mengembangkannya dengan membaca referensi-referensi pendukung agar tujuan dari setiap praktikum tercapai. Namun kadangkali kegiatan berpraktikum menimbulkan persoalan mengenai kerjasama antarmahasiswa dalam kelompok atau antarmahasiswa antarkelompok. Kemampuan komunikasi peserta didik tentu tidak bisa muncul sendiri tanpa perantara yaitu dosen itu sendiri. Kesadaran untuk meraih tujuan belajar bersama masih terabaikan karena egoisitas masing-masing mahasiswa. Kemampuan interaksi ini juga sebagai indikator keaktifan peserta didik dalam kegiatan pembelajaran, sekaligus sebagai karakteristik dari pembelajaran berbasis kurikulum tematik. (Ibnu Hajar, 2013: 53). Hal ini diupayakan sebagai persiapan mahasiswa calon guru agar siap menghadapi kurikulum 2013 yang akan diimplementasikan pada tahun 2018.

Ciri menonjol budaya modernitas antara lain berkembangnya paham individual (Wiendu Nuryanti, 2013: 19), sehingga banyak egoisitas mahasiswa terlihat dalam kegiatan praktikum. 
Kegiatan berpraktikum di samping dibutuhkan kekompakan dan kerjasama juga perlu dibangun iklim keterbukaan, agar nantinya ilmu itu tidak tersumbat sehingga menimbulkan rasa kegelisahan karena kekurangbanyakan informasi yang didapatkan saat praktikum berlangsung. Keterbukaan berpikir sains dengan bertanya W5H1 diperlukan agar nantinya mahasiswa setelah praktikum tidak muncul persoalan baru dan harus bertanya-tanya lagi mengenai masalah yang diharapkan selesai seketika. Ketuntasan belajar saat sedang praktikun diperlukan agar nantinya semua berjalan dengan baik.

Dikarenakan universitas riset merupakan lembaga pusat dalam semua komunitas ilmu pengetahuan dan teknologi, serta dikarenakan mereka dianggap sebagai kunci untuk mencapai sistem pendidikan kelas dunia, maka masa depan mereka dapat dikatakan cerah (Altbact, 2013: 27). Di samping itu kegiatan berpraktikum semestinya harus membangun kerja sama dan keterbukaan berpikir ilmiah mahasiswa Program Pendidikan Guru Sekolah Dasar yang kemudian disingkat PGSD karena kerjasama dan keterbukaan berpikir ilmiah adalah ciri sosok seorang guru Sekolah Dasar (SD). Kalau praktikum itu menjadikan mahasiswa menjadi egois dan tidak berpikir terbuka maka maka akan menjadikannya beban. Oleh karena itu, mata kuliah berpraktikum untuk sains lanjut harus dievaluasi kembali perlu atau tidak. Oleh karena itu penulis ingin meneliti mahasiswa PGSD yang melakukan praktikum di Laboratorium FMIPA kampus 3.

\section{Metode Penelitian}

Jenis penelitian yang digunakan penulis adalah Penelitian Tindakan Kelas. Penulis ingin mengetahui peningkatan kerjasama antarkelompok mahasiswa yang sedang melakukan praktikum di laboratorium serta untuk mengetahui efektifitas membangun keterbukaan berpikir ilmiah yang akan dilaksanakan.

Dalam fase perencanaan peneliti menemukan beberapa masalah yaitu mahasiswa kurang kompak dalam hal bekerja sama antarkelompok, mahasiswa kurang aktif saat proses praktikum, mahasiswa kurang bersemangat dalam praktik, mahasiswa ribut saat proses pembagian praktik, dan mahasiswa belum terlihat diskusi atau bertukar pikiran atau bertukar pendapat. Metode praktikum yang digunakan adalah metode kerja kelompok yang bermakna.

Penelitian dilaksanakan di Program Studi PGSD Semester 3. Subjek penelitian adalah semua mahasiswa pada mata kuliah sains lanjut yang terdistribusi dalam 7 kelas A, B, C, D, E, F, dan G. Namun, hanya kelas D, E, F, dan G yang digunakan untuk penelitian karena penulis adalah pengampu mata kuliah tersebut dan memantau langsung pelaksanaan praktikum sains lanjut. Adapun distribusi mahasiswa terdiri dari 46 mahasiswa kelas D, 43 kelas E, 
47 kelas F, dan 35 kelas $\mathrm{G}$, sehingga jumlah total sampel yang digunakan adalah 171 mahasiswa.

Masalah yang diteliti adalah kerjasama antarkelompok dan keterbukaan berpikir ilmiah. Mahasiswa dalam mata kuliah sains lanjut. Observasi dilaksanakan waktu penelitian, teknik yang dilakukan adalah teknik obervasi terstruktur. Dalam melakukan observasi peneliti menggunakan pedoman berupa angket dan lembaran obervasi. Observasi ini dilakukan selama penelitian berlangsung agar data yang didapatkan valid. Kegiatan penelitian dilaksanakan secara sistematis, yaitu penelitian dilakukan tahap demi tahap untuk mengetahui tingkat kemampuan mahasiswa setelah perbaikan dilakukan.

Adapun kegiatan yang dilakukan antara lain Menganalisa data. Untuk data tentang kerjasama antarkelompok mahasiswa dianalisis dengan cara penilaian setiap mahasiswa. Mahasiswa mengisi angket yang telah dikembangkan peneliti sesuai indikator kerjasama antarkelompok dengan 5 skala Likert dengan 20 pernyataan. Adapun penilaiannya adalah $\mathrm{A}=$ Sangat baik $(80-$ 100) $\mathrm{B}=$ Baik $(70-79) \mathrm{C}=$ Cukup $(60-69)$ $\mathrm{D}=$ Kurang $(50-59) \mathrm{E}=$ Sangat kurang $(50$ ke bawah). Sedangkan membangun keterbukaan berpikir ilmiah dengan memberikan angket keterbukaan berpikir ilmiah dengan menggunakan model 5 skala likert dengan 20 pernyataan positif dan negatif. Adapun penilaiannya adalah $\mathrm{A}=$ Sangat baik $(80-100) \mathrm{B}=$ Baik $(70-79) \mathrm{C}=$ Cukup $(60$ - 69) D = Kurang (50 - 59) E = Sangat kurang (50 ke bawah).

Indikator keberhasilan dari penelitian ini adalah kerjasama antarkelompok dan keterbukaan berpikir ilmiah saat berpraktikum dalam penelitian ini dapat ditetapkan berhasil jika kualifikasinya berkategori baik atau dengan nilai paling rendah 70 .

\section{Hasil Penelitian dan Pembahasan}

Terdapat beberapa faktor yang dapat memengaruhi kegiatan proses pembelajaran di antaranya faktor guru, faktor siswa, sarana, alat, dan media yang tersedia, serta faktor lingkungan (Wina Sanjaya, 2012: 2) salah satunya adalah laboratorium. Laboratorium merupakan tempat atau lainnya yang dilengkapi dengan peralatan untuk mengadakan percobaan dan sebagainya (Tim Penyusun Kamus, 1994). Laboratorium adalah merupakan suatu tempat di mana percobaan dan penyelidikan dilakukan. Secara internasional, topik yang tidak mendapat perhatian serius adalah melakukan eksperimen (Bahrul Hayat, 2010: 383). Eksperimen merupakan suatu kegiatan yang menyenangkan di suatu tempat tertentu.Tempat yang dimaksudkan dapat merupakan suatu ruangan tertutup, kamar atau ruangan terbuka, kebun misalnya. Secara terbatas, laboratorium dapat dipandang sebagai suatu ruangan yang tertutup 
di mana suatu percobaan dan penyelidikan dilakukan (Depdikbud, 1997). Umumnya ruangan dalam hal ini adalah tempat berlangsungnya kegiatan pembelajaran secara praktek yang memerlukan peralatan khusus yang tidak mudah dihadirkan di ruang kelas.

Pergeseran telah membawa pengaruh pada perubahan pola, metode, dan strategi penyajian pembelajaran, di samping pendekatan yang digunakan juga ikut bergeser. (Asmani, 2011: 116). Dalam pembelajaran sains, laboratorium merupakan bagian integral dari kegiatan belajar mengajar. Hal ini dikarenakan mahasiswa tidak hanya sekadar mendengarkan keterangan dosen atau asisten praktikum dari mata kuliah yang telah diberikan, tetapi harus melakukan kegiatan sendiri untuk mencari keterangan lebih lanjut tentang ilmu yang dipelajarinya.

Dengan adanya laboratorium, maka diharapkan proses pengajaran sains dapat dilaksanakan seoptimal mungkin, meskipun bukan berarti sains tidak dapat diajarkan tanpa laboratorium. Dari sisi ini tampak betapa penting peranan kegiatan laboratorium untuk mencapai tujuan pendidikan sains dalam hal kerja sama dan keterbukaan berpikir ilmiah.

Kerjasama dalam praktikum dapat dilihat dari kekompakan, saling mengisi satu sama lain, saling berbagi tugas sesuai jobdesk, dan saling menghargai kelompok lain. Keterbukaan berpikir ilmiah dapat diartikan sebagai sikap memiliki perhatian besar terhadap ilmu pengetahuan atau kebiasaan berpikir ilmiah. Adapun keterbukaan berpikir ilmiah dapat dilihat dari indikator mampu berpikir kritis, memiliki kemauan belajar yang kuat, mampu bekerja sama yang baik dalam kelompok, jujur dan objektif, bertindak teliti dan cermat, serta terbuka.

Sifat-sifat di atas menunjukkan arah dan tujuan yang hendak dicapai seseorang yang hendak menumbuhkan keterbukaan berpikir ilmiah, sebagaimana jiwa-jiwa sikap yang lain, mungkin diresapi daripada yang diajarkan. Jiwa dan semangat itu sering didapatkan dari pergaulan seseorang dengan seseorang yang berhasil mengembangkan semangat itu di dalam kehidupannya (Maskoeri Jasin, 2002: 54-55).

Adapun hasil penelitian antarsiklus adalah sebagai berikut.

Tabel Hasil Penelitian Secara Global

\begin{tabular}{|l|c|c|c|}
\hline \multicolumn{1}{|c|}{$\begin{array}{c}\text { Variabel } \\
\text { yang diteliti }\end{array}$} & $\begin{array}{c}\text { Rata- } \\
\text { rata } \\
\text { Siklus I }\end{array}$ & $\begin{array}{c}\text { Rata- } \\
\text { rata } \\
\text { Siklus } \\
\text { II }\end{array}$ & Peningkatan \\
\hline $\begin{array}{l}\text { Kerjasama } \\
\text { antar } \\
\text { kelompok }\end{array}$ & 74,31 & 78,46 & 4,15 \\
\hline $\begin{array}{l}\text { Keterbukaan } \\
\text { berpikir } \\
\text { Ilmiah }\end{array}$ & 82,98 & 87,12 & 4.14 \\
\hline
\end{tabular}

Dari tabel di atas sudah terjadi peningkatan yang berarti hal ini menunjukkan 
bahwa mata kuliah berpraktikum sangat mendukung terjadinya peningkatan kerjasama antarkelompok dan keterbukaan berpikir ilmiah. Setidaknya ada 4 alasan yang menguatkan peran laboratorium dalam pembelajaran di kampus antara lain yang pertama praktikum membangkitkan semangat bekerja sama dalam praktikum sains lanjut. Dalam belajar, mahasiswa dipengaruhi oleh motivasi. Mahasiswa yang termotivasi untuk belajar akan bersungguh-sungguh dalam mempelajari sesuatu dalam suatu kelompok praktikum. Melalui kegiatan laboratorium, mahasiswa diberi kesempatan untuk memenuhi dorongan rasa ingin tahu dan ingin bisa. Prinsip ini akan menunjang kegiatan praktikum di mana mahasiswa menemukan pengetahuan melalui eksplorasi dari berbagai sumber yang mendukung kegiatan praktikum selain modul. Yang kedua praktikum mengembangkan keterampilan dasar melakukan eksperimen. Kegiatan eksperimen merupakan aktivitas yang banyak dilakukan oleh ilmuwan. Untuk melakukan eksperimen diperlukan beberapa keterampilan dasar seperti mengamati, mengestimasi, mengukur, membandingkan, memanipulasi peralatan laboratorium, dan keterampilan sains lainnya.

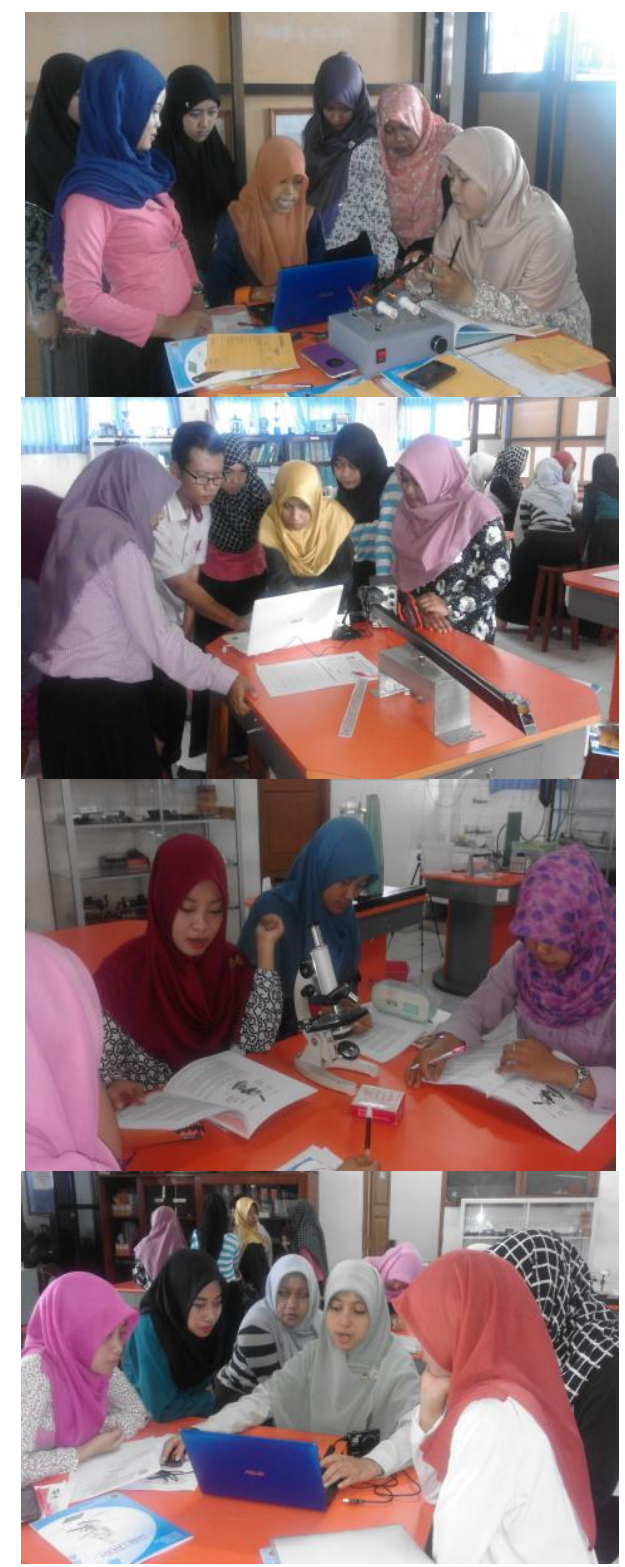

Gambar. Mahasiswa PGSD Melakukan

\section{Praktikum Sains Lanjut}

Dengan adanya kegiatan praktikum di laboratorium akan melatih mahasiswa untuk mengembangkan kemampuan bereksperimen dengan melatih kemampuan mahasiswa dalam mengobservasi dengan cermat, mengukur secara akurat dengan alat ukur yang sederhana atau lebih canggih, menggunakan dan menangani alat secara aman, merancang, melakukan dan menginterpretasikan 
eksperimen secara berkelompok. Yang ketiga praktikum menjadi wahana belajar pendekatan ilmiah. Para ahli meyakini bahwa cara yang terbaik untuk belajar pendekatan ilmiah adalah dengan menjadikan mahasiswa sebagai ilmuwan. Pembelajaran sains sebaiknya dilaksanakan melalui pendekatan scientific inquiry untuk menumbuhkan kemampuan berpikir, bekerja dan bersikap ilmiah serta mengkomunikasikannya sebagai aspek penting kecakapan hidup. Oleh karena itu pembelajaran sains di kampus menekankan pada pemberian pengalaman belajar secara langsung melalui penggunaan dan pengembangan keterampilan proses dan berpikir ilmiah. Yang keempat praktikum menunjang materi pelajaran. Praktikum memberikan kesempatan bagi mahasiswa untuk menemukan teori, dan membuktikan teori. Selain itu, praktikum dalam pembelajaran sains dapat membentuk ilustrasi bagi konsep dan prinsip sains.

Dari kegiatan tersebut dapat dijelaskan bahwa praktikum dapat menunjang pemahaman mahasiswa terhadap materi pelajaran dalam hal kerjasama dan keterbukaan berpikir ilmiah. Selanjutnya secara lebih rinci dapat dijelaskan bahwa, laboratorium sains berperan penting dalam kegiatan perkuliahan yaitu dengan menumbuhkan dan mengembangkan aspek-aspek antara lain: keterampilan dalam pengamatan, pengukuran, dan pengumpulan data, kemampuan menyusun data dan menganalisis serta menafsirkan hasil pengamatan, kemampuan menarik kesimpulan secara logis berdasarkan hasil eksperimen, mengembangkan model dan menyusun teori, kemampuan mengkomunikasikan secara jelas dan lengkap hasil-hasil percobaan, keterampilan merancang percobaan, urutan kerja, dan pelaksanaannya, keterampilan dalam memilih dan mempersiapkan peralatan dan bahan untuk percobaan, keterampilan dalam menggunakan peralatan dan bahan, kedisiplinan dalam mematuhi aturan dan tata tertib demi keselamatan kerja.

Dengan berpraktikum mahasiswa akan meningkatkan keterbukaan berpikir ilmiah dengan ditandai dengan aktif bertanya, mengeluarkan ide-ide atau gagasan dan selalu menghargai perbedaan pendapat. Pikiran seperti parasut, keduanya bekerja pada saat terbuka." Frank Zappa melantunkan syair ini dalam lagunya. Pikiran dan parasut sama-sama berfungsi untuk 'menyelamatkan' manusia. Pikiran menyelamatkan manusia dari kebingungan, kekacauan, dam bahaya-bahaya penggunaan informasi secara tak tepat. Keterbukaan berpikir dapat menyelamatkan manusia dari berbagai macam kerugian, kenistaan, dan keterbelakangan.

Berpikir adalah kegiatan mental yang dilakukan mahasiswa untuk mengolah informasi, baik yang diperoleh dari lingkungan maupun yang sudah ada dalam benak. Informasi adalah segala sesuatu yang dapat dipersepsi oleh mahasiswa. Sedangkan kegiatan mengolah informasi meliputi meliputi kegiatan menanggapi dan mencipta informasi. Dalam proses ini mahasiswa 
menanggapi informasi yang dimilikinya, menafsirkan makna dan maksud informasi, merekareka pengaruh informasi itu terhadap diri, serta menimbang-nimbang seberapa jauh keteranganketerangan yang dikandung informasi itu penting bagi diri dan orang lain. Kegiatan menanggapi informasi yang dimiliki itu seringkali menghasilkan satu informasi baru, dengan kata lain dalam kegiatan ini mahasiswa menciptakan informasi baru. Informasi baru ini dapat berbentuk kesimpulan atau pertanyaan.

Berpikir harus selalu melibatkan informasi. Tanpa informasi, mahasiswa tidak dapat berpikir. Semakin banyak informasi, semakin lancar kegiatan berpikir. Implikasinya, semakin banyak mahasiswa mampu menyerap informasi, semakin mampu berpikir dengan baik. Kemampuan menyerap informasi mensyaratkan adanya keterbukaan dalam benak (pikiran) mahasiswa. Sedangkan pikiran yang tidak terbuka, mahasiswa masih dapat berpikir, namun kegiatan berpikirnya lebih menyerupai kegiatan instingtif. Kegiatan berpikir yang dilakukan hanya sekadar pengulangan dari yang sudah dilakukan orang-orang terdahulu. Apabila mahasiswa tidak dapat berpikir kecelakaan lebih mungkin terjadi. Tanpa berpikir manusia hanya mengandalkan insting. Ia tidak tahu bagaimana menemukan cara baru untuk menghindari bencana, mencegah terjadinya kecelakaan dan menangani akibat kecelakaan.

Dengan kemampuannya menggunakan simbol, manusia dapat mengkomunikasikan ide-ide, pengalaman-pengalaman, dan pengetahuannya kepada mahasiswa lain. Seorang mahasiswa yang sudah pernah mengunjungi suatu tempat dapat menceritakan pengalamannya berada di tempat itu kepada mahasiswa lain yang belum pernah mengunjungi tempat itu. Pengetahuan yang dimiliki seseorang dapat dikomunikasikan dengan orang lain sehingga dapat terjadi penyebaran dan pertukaran pengetahuan. Mahasiswa pun dapat mengetahui berbagai hal tanpa harus langsung berhadapan dengan hal-hal itu. Dengan waktu yang sedikit ia dapat menyerap banyak pengetahuan. Komunikasi mahasiswa juga berkembang melalui media-media elektronik seperti TV, radio, telepon, dan internet. Mahasiswa terus membuka diri bagi berbagai kemungkinan baru, terus mengutak-atik dunianya.

Kemajuan yang dicapai mahasiswa sekarang tidak diperoleh dalam waktu yang singkat. Kemajuan itu dicapai lewat berbagai usaha pemahaman terhadap alam, perilaku manusia, dan usaha-usaha manusia menemukan serta menciptakan hal-hal baru. Kemajuan itu dicapai melalui proses kerja yang panjang dan melibatkan begitu banyak orang. Dari sanalah mahasiswa belajar. Mahasiswa dari kemajuankemajuan yang sudah dicapai manusia lain. Mahasiswa belajar dari lingkungan dan pengalaman orang lain. Hasil belajarnya itu nantinya akan digunakan sebagai bahan masukkan paling tidak sebagai penggugah dan motivator untuk menciptakan hal-hal yang baru.

Keterbukaan pikiran sangat dibutuhkan. Dengan keterbukaan pikiran yang tinggi tingkat penerimaan terhadap informasi menjadi lebih tinggi. kesiapan mahasiswa untuk menerima pengetahuan-pengetahuan baru, contoh-contoh 
yang baik, alternatif solusi, dan berbagai rujukan lainnya, semakin tinggi. Keterbukaan pikiran mensyaratkan adanya kompleksitas pikiran yang tinggi. Kompleksitas pikiran adalah derajat kemampuan untuk memandang suatu masalah dari berbagai sudut pandang dan menyelesaikannya dengan melibatkan berbagai sudut pandang pula. Dengan kompleksitas pikiran yang tinggi, mahasiswa mampu melakukan differensiasi dan integrasi dalam menanggapi berbagai hal yang dihadapinya. persepsi terhadap dimensi-dimensi yang berbeda dari setiap hal yang menjadi objek perhatian.

Kompleksitas pikiran merupakan suatu faktor pada diri manusia yang berperan dalam menentukan kemampuan penerimaan terhadap berbagai pandangan, pendapat dan penilaian yang berbeda-beda serta kemampuan untuk memandang suatu hal dari berbagai sudut pandang yang berbeda-beda. Semakin tinggi kompleksitas pikiran seseorang, semakin tinggi kemampuannya menerima berbagai pandangan, pendapat dan penilaian yang berbeda-beda dan semakin tinggi pula kemampuannya untuk memandang suatu hal dari berbagai sudut pandang yang berbeda-beda.

Kebiasaan bertukar peran dengan orang lain yang memiliki latar belakang berbeda meningkatkan kemampuan seseorang dalam menilai suatu hal dari berbagai sudut pandang (Kohlberg, 1984). Begitu pula dengan kebiasaan diskusi dengan pihak-pihak dari berbagai latar belakang. Kedua faktor ini meningkatkan kemampuan diferensiasi yang merupakan unsur dari kompleksitas pikiran.

Sistem nilai berperan sebagai standar bertingkah laku serta menjadi patokan evaluasi terhadap diri sendiri dan orang lain. Ketika menghadapi suatu situasi tertentu sistem nilai memberi saran-saran kepada individu untuk bertindak. Di sini sistem nilai untuk memberikan petunjuk secara umum pada kegiatan pengambilan keputusan, mengarahkan tingkah laku untuk mencapai tujuan, serta membantu memilih tingkah laku tertentu agar tujuan tertentu dapat dicapai. nilai yang mendukung keterbukaan pikiran mengarahkan manusia untuk terbuka. Oleh karena itu, agar derajat komplesitas yang tinggi dapat dimiliki oleh seseorang, maka orang itu harus diarahkan untuk menganut nilai yang menekankan pentingnya keterbukaan pikiran.

Keterbukaan pikiran perlu mendapat perhatian serius mengingat Indonesia adalah negara dengan beragam suku bangsa dan agama. Kehidupan bersama yang dilalui masyarakat Indonesia adalah kehidupan yang membutuhkan toleransi yang besar, menghargai perbedaan, dan kesiapan menerima berbagai pendapat yang tak sejalan. Kegiatan komunikasi yang dilakukan dalam diskusi, tanya-jawab, permainan-permainan yang melibatkan proses komunikasi, dan memberikan umpan balik kepada pendapat orang lain. Ketika terlibat dalam berbagai 
permasalahan terbina komunikasi antarorang yang ikut ambil bagian dalam penyelesaian masalah-masalah di dalamnya. Harus ada jaminan terhadap kebebasan berpendapat bagi semua pihak serta tersebarnya informasi secara jelas, lengkap, dan jujur. Pebedaan pendapat memungkinkan diperolehnya satu keputusan yang kaya karena memuat berbagai pikiran dari pendapat-pendapat yang berbeda. Kebiasaan berhadapan dengan berbagai pendapat yang berbeda akan meningkatkan kompleksitas pikiran masyarakat Indonesia.

Sebenarnya ilmu yang lain juga menggunakan kaidah yang sama dengan pengembangan sains tetapi ada salah satu faktor yang membedakan sains dibanding mata kuliah lain di perguruan tinggi yakni adanya kegiatan praktek dan eksperimen yang melibatkan mahasiswa atau asisten dan mahasiswa dengan bahan pembelajaran seperti prosedur percobaan dan pemakaian alat dan bahan, yang biasanya dilakukan di laboratorium.

Laboratorium menempati kedudukan sangat penting dalam pembelajaran maupun pengembangan sains, karena laboratorium sebenarnya adalah jantungnya sains. Laboratorium berperan sebagai tempat untuk memberikan suatu ilustrasi materi teoritik bersifat verifikatif untuk membuktikan hasil penelitian di laboratorium maupun sebagai tempat mahasiswa untuk mendapatkan kesempatan melakukan pengalaman langsung dalam memecahkan masalah yang diangkat dari fenomena alam yang diamati atau teori yang mahasiswa pelajari. Kegiatan laboratorium hendaknya dirancang dengan tujuan melatih mahasiswa untuk mengorganisasikan kegiatan ilmiah yang meliputi aktivitas-aktivitas: melakukan observasi dan pengukuran, menemukan suatu masalah dan mencari cara pemecahannya, menginterpretasikan dan memformulasikan, generalisasi, menyusun, menguji, dan merevisi suatu model.

Ciri utama dari kegiatan ilmiah adalah melakukan penalaran disertai dengan pengujian secara empirik. Menalar merupakan kegiatan mental dalam mengembangkan pikiran terhadap suatu fakta atau prinsip. Usaha mengembangkan pikiran tersebut dapat dalam bentuk menentukan korelasional, membuat suatu keputusan atau evaluasi berdasarkan landasan pemikiran tertentu, melakukan prediksi, menyusun kesimpulan, memberikan alasan tentang penyebab suatu kejadian. Hasil penalaran itu kemudian diuji secara empiris, dalam arti dicarikan bukti-bukti empiris yang menunjang hasil penalaran tersebut. Untuk mendapatkan bukti empirik dari suatu gagasan hasil penalaran diperlukan kegiatan laboratorium. Jadi kegiatan laboratorium sebenarnya merupakan jembatan antara hasil kegiatan intelektual yang bersifat rasional dengan bukti-bukti empirik berupa fakta yang 
diperoleh melalui cara-cara pengujian yang bersifat metodologis atau prosedural.

Sains merupakan suatu mata pelajaran yang memberikan kesempatan kepada para mahasiswa untuk berpikir kritis melalui kegiatan-kegiatan yang dilakukan sendiri oleh mahasiswa. Inisiatif yang dibangun dari proses komunikasi terbuka, hasil diskusi dan tukar pikiran akan menambah semangat mereka dalam bekerja (Daryanto: 2015: 112). Kegiatan-kegiatan yang dimaksud dapat dilangsungkan di dalam laboratorium berkaitan dengan suatu bidang ilmu tertentu yang antara lain ditujukan untuk menunjang pembelajaran teori. Proses belajar mengajar yang demikian disebut sebagai kegiatan praktikum. Melalui kegiatan praktikum mahasiswa diberi kesempatan untuk mengalami sendiri atau melakukan sendiri, seperti mengikuti suatu proses, mengamati suatu objek, menganalisis, membuktikan dan menarik kesimpulan sendiri mengenai suatu objek, keadaan atau proses sesuatu. mahasiswa dapat mengalami sendiri, mencari kebenaran, atau mencoba mencari suatu hukum atau dalil, dan menarik kesimpulan atas proses yang dialaminya itu.

Beberapa ahli mempunyai pandangan yang berbeda terhadap kegiatan laboratorium, sehingga melahirkan beberapa model dan metode praktikum, seperti misalnya: model praktikum induktif, model praktikum verifikasi, dan metode inkuiri. Model praktikum induktif dikembangkan oleh penganut faham Francis Bacon yang berpendapat bahwa pekerjaan saintis adalah mengumpulkan pola hubungan antardata dan selanjutnya menemukan teori untuk merasionalisasi semua itu. Model praktikum verifikasi dikembangkan oleh penganut faham Popper yang mamandang saintis mengawali penyelidikannya dengan suatu hipotesis yang diturunkan dari penyatuan pengalaman dan kreativitas. Kegiatan praktikum model verifikasi ini lebih diarahkan pada pembuktian teori yang telah dipelajari mahasiswa sebelumnya. Metode inkuiri dikembangkan melalui pendekatan heuristik yang memandang saintis sebagai penemu (discoverer).

Kegiatan praktikum menurut pandangan ini, mahasiswa dianggap seperti saintis yang sedang melakukan eksperimen, mereka dituntut untuk merumuskan masalah, merancang eksperimen, merakit alat, melakukan pengukuran secara cermat, menginterpretasikan data perolehan, serta mengkomunikasinnya melalui laporan yang harus dibuatnya. Tujuan pembelajaran sains di kampus antara lain: sains sebagai produk, sains sebagai proses, sainsteknologi dan masyarakat untuk pengembangan sikap dan nilai, dan pendekatan ketrampilan personal dan sosial.

Secara keseluruhan berbagai kemungkinan tujuan pengajaran sains ini dapat diwujudkan melalui pengajaran sains di laboratorium. Dalam hal sains sebagai sebuah produk, maka praktik laboratorium dan 
eksperimen merupakan bagian yang esensial dalam perkuliahan sains. Melalui kegiatan laboratorium, dapat terjadi transformasi dari pengalaman menuju generalisasi ilmiah dan pembuatan teori.

Pembelajaran sains melalui praktikum di laboratorium dapat berperan untuk memberikan realitas yang lebih nyata daripada sekadar penjelasan tertulis, untuk memberikan bayangan realitas yang memang butuh penjelasan, untuk melatih penggunaan alat-alat laboratorium dan teknik penggunaannya; dan untuk menguji atau mengkonfirmasi perkiraanperkiraan teori-teori ilmiah. Hal yang sangat mendasar dari dikembangkannya kegiatan laboratorium adalah untuk melatih dan mengembangkan keahlian siswa dalam memecahkan masalah secara ilmiah.

Ketika tujuan ini ditetapkan hal yang perlu dilakukan dosen untuk memaksimalkannya adalah memberikan kesempatan waktu pada mahasiswa yang lebih banyak supaya mahasiswa dapat berpikir, berdiskusi, membuat perencanaannya sendiri dan untuk berefleksi atas hasil yang didapat. Adapun untuk pembelajaran sains-teknologi dan masyarakat, terdapat dua komponen yang terintegrasi yakni sains itu sendiri dan cara sains berinteraksi dalam kehidupan pribadi dan masyarakat. Dosen sains sebaiknya dapat menarik perhatian mahasiswa dengan melibatkan apa yang diajarkan dengan kehidupan sehari-hari di lingkungan mahasiswa berada. Dengan melibatkan mahasiswa dalam praktek laboratorium maka dapat dikembangkan sikap-sikap yang bermanfaat yang kelak dapat digunakan mahasiswa setelah terjun di masyarakat.

Di samping berbagai potensi yang dapat digunakan, praktikum laboratorium yang selama ini dilakukan di perguruan tinggi juga memiliki keterbatasan. Sebagai contoh, ketika pembelajaran sains yang dilakukan dengan metoda praktek laboratorium dibandingkan dengan metoda lainnya. Ternyata tidak menunjukkan peningkatan prestasi mahasiswa kecuali dalam hal keterampilan mahasiswa dalam penggunaan alat-alat laboratorium. Dosen yang pernah melakukan praktek laboratorium juga mengalami, bahwa praktek laboratorium membutuhkan waktu yang lebih banyak untuk persiapan alat dan bahan, kesulitan dalam mengatur dan mengawasi mahasiswa dalam berpraktek, prosedur percobaan yang sulit dipahami mahasiswa dan kemungkinan mahasiswa membuat kesalahan di setiap saat, dan hasil yang diinginkan dan pemahaman yang diharapkan dari mahasiswa pun biasanya jauh dari yang direncanakan dari kegiatan praktek tersebut.

Pada umumnya kegiatan praktek laboratorium diarahkan pada upaya supaya mahasiswa dituntut untuk menguji, memverifikasi atau membuktikan hukum atau prinsip ilmiah yang sudah dijelaskan oleh dosen atau buku kuliah. Ada juga percobaan 
yang dirancang oleh dosen adalah para mahasiswa disuruh melakukan percobaan dengan prosedur yang sudah terstruktur yang membawa mahasiswa kepada prinsip atau hukum yang tidak diketahui sebelumnya dari data empiris yang mereka kumpulkan hasil dari percobaan tersebut. Namun terdapat berbagai kelemahan dasar dari cara seperti ini, secara logis prinsip ilmiah dan hukum alam tidak dapat dibuktikan secara langsung; prinsip ilmiah dan hukum alam juga tidak dapat diuji hanya dengan jumlah percobaan yang terbatas yang dilakukan oleh mahasiswa. Keterbatasan alat yang digunakan, keterampilan yang dipunyai, waktu yang singkat dan kompleksitas generalisasi, merupakan keterbatasan percobaan mahasiswa yang menunjukkan hal yang hebat kalau mahasiswa dapat menghasilkan prinsip teoritis yang penting dari sekumpulan data mentah hasil percobaan.

Dengan memperhatikan berbagai keterbatasan pengajaran sains dengan metoda laboratorium dan hasil yang diinginkan, van den Berg dan Giddings (1992) menyarankan jenis kegiatan yang efektif dilakukan adalah: mengembangkan keterampilan dan teknik (pelatihan), memberikan pengalaman yang nyata (pengalaman) dan memberikan pelatihan pemecahan masalah (investigasi). Pelatihan adalah mengembangkan keterampilan praktek dan teknik mahasiswa. Kebutuhan akan kegiatan ini adalah untuk mengenalkan mahasiswa dan melibatkan mereka lebih dekat lagi dengan alat, bahan dan prosedur kerja di laboratorium. Jenis-jenis kegiatan yang dilakukan di antaranya adalah pengamatan (observasi), pengukuran, pendugaan (estimasi) dan manipulasi. Diharapkan melalui jenis kegiatan ini mahasiswa mempunyai pengetahuan dan keterampilan penting sebelum melakukan kegiatan lainnya di laboratorium.

Pengalaman adalah kegiatan laboratorium yang sifatnya memberikan interaksi langsung yang nyata pada mahasiswa melalui panca inderanya. Karena mata kuliah Sains Lanjut salah satunya bertujuan untuk memberi arti tentang dunia fisik dimana manusia hidup, maka sudah sewajarnya mahasiswa dapat merasakan dan mengalami petualangan kuliah Sains Lanjut melalui kegiatan eksperimentasi. Kegiatan eksperimentasi pengalaman bermaksud mengajarkan konsep Sains dengan kegiatan praktek/percobaan secara terintegrasi dan juga bisa mengarah pada ilustrasi di mana dosen atau asisten praktikum dan mahasiswa sudah sedikit tahu tentang konsep Sains dan kesimpulan yang kemungkinan dituju.

Setelah mahasiswa menguasai berbagai keterampilan kerja di laboratorium dan memahami serta mengenali beragam konsep Sains yang penting, maka mereka dapat melakukan aktivitas laboratorium yang lebih tinggi tingkatannya, kegiatan ini dinamakan investigasi. Kegiatan investigasi paling tidak terdapat dua jenis, pertama jawaban akhir tidak 
diberikan tetapi terdapat bimbingan mengenai bagaimana cara untuk menyelesaikan masalah dan ada harapan hasil seperti apa yang diinginkan; kedua adalah investigasi yang bersifat terbuka, aktivitas ini tidak harus selalu mendapat jawaban bahkan mungkin tidak terdapat penyelesaian yang memuaskan sehingga mahasiswa bertanggungjawab penuh terhadap seluruh proses dari upaya penyelesaian masalah, koleksi data, membuat kesimpulan dan kemungkinan penyelesaian.

\section{Simpulan}

Kesimpulan penelitian PTK ini sebagai berikut.

1. Ada peningkatan kerjasama antarkelompok. Peningkatan kerjasama antarkelompok ditunjukkan dengan kenaikan skor rata-rata 74,31 siklus I menjadi 78,46 pada siklus II.

2. Ada peningkatan keterbukaan berpikir ilmiah. Peningkatan keterbukaan berpikir ilmiah ditunjukkan dengan kenaikan skor rata-rata 82,98 siklus I menjadi 87,12 siklus II.

\section{Daftar Pustaka}

Bahrul Hayat dan Suhendra Yusuf. 2010. Mutu Pendidikan. Jakarta: Bumi Aksara
Daryanto. 2015. Pengelolaan Budaya dan Iklim Sekolah. Yogyakarta: Gava Media Ibnu Hajar. 2013. Panduan Lengkap

Kurikulum Tematik untuk SD/MI.

Yogyakarta: Diva Press

I Wayan Suwatra. 2014. Sosiologi pendidikan.

Yogyakarta: Graha Ilmu

Jamal Ma'mur Asmani. 2011. Tips Efektif

Pemanfaatan Teknologi Informasi dan

Komunikasi dalam Dunia Pendidikan.

Yogyakarta: Diva press

Ki Hajar Dewantara. 1997. Karya Ki Hadjar

Dewantara. Yogyakarta: majelis luhur

Persatuan Taman Siswa

Maskoeri Jasin. 2002. Ilmu Alamiah Dasar

untuk Perguruan Tinggi dan Umum.

(Jakarta: Raja Grafindo Persada

Philip G. Altbach. 2013. The Road to Academic

Excellence The Making of World-Class

Research Universities. Jakarta: Salemba

Humanika.

Supardi. 2013. Sekolah Efektif. Konsep Dasar dan Praktiknya. Jakarta: Rajawali Press.

Wiendu Nuryanti. 2013. Strategi Kebudayaan. Malang: UB Press

Wina Sanjaya. 2012. Media Komunikasi

Pembelajaran. Yogyakarta: Kencana

Prenada Media Group 